\title{
DIALOG DAN TINDAKAN KOLEKTIF KELOMPOK TANI DALAM PROGRAM SERTIFIKASI KAKAO DI PROVINSI SULAWESI BARAT
}

\section{Dialogue and Collective Action of Farmer Groups on Cocoa certification program in West Sulawesi Province}

\author{
Nur Asia ${ }^{1}$, Sarwititi Sarwoprasodjo ${ }^{2}$, Dyah Gandasari ${ }^{3}$ \\ ${ }^{1}$ Dinas Pertanian Provinsi Sulawesi Barat \\ ${ }^{2}$ Program Studi Komunikasi Pembangunan Pertanian dan Pedesaan, SPs-IPB \\ ${ }^{3}$ Sekolah Tinggi Penyuluhan Pertanian Kementerian Pertanian \\ E-mail : nurasia.tam@gmail.com
}

\begin{abstract}
The cocoa certification program is the implementation of cocoa management practices that meet sustainable agricultural standards. This program is part of the commitment of cocoa sector stakeholders to realize sustainable cocoa. West Sulawesi Province is one of cocoa production centers in Indonesia. The implementation of cocoa certification in this province is still low, about $8.4 \%$ of the total cocoa farmers. This study aims to determine the potential for sustainability of the adoption of Cocoa Certification from development communication aspect by conducting an assessment on dialogue and collective action of farmer groups. The research conducted in Luyo Sub-District Polewali Mandar District West Sulawesi Province using survey method with descriptive correlation analysis. The sample size is 41 groups with 205 respondents. Descriptive analysis shows the average index of the implementation of community dialogue and collective action of 56.05,50,88 and 65.72 from a maximum score of 100. The results indicated that perception of farmers on the observability of Cocoa Certification and the role of facilitators are significant related to dialogue and collective action of farmer groups. The dialogue in the group is significant correlated with their collective action. So, some farmer groups have potential to continue to adopt the Cocoa Certification standard but others have potential to quit.
\end{abstract}

Keywords : adoption of innovation, cocoa certification, collective action, community dialogue, facilitator

\begin{abstract}
ABSTRAK
Program Sertifikasi Kakao merupakan penerapan praktik pengelolaan kakao yang ditujukan untuk memenuhi standar pertanian berkelanjutan, dan dilaksanakan sebagai implementasi komitmen seluruh pelaku sektor kakao mewujudkan sustainable cocoa. Sebagai salah satu sentra produksi kakao utama di Indonesia, tingkat adopsi praktik budidaya standar Sertifikasi Kakao di Sulawesi Barat masih rendah, berkisar $8,4 \%$ dari total petani kakaonya. Penelitian ini bertujuan mengetahui potensi keberlanjutan adopsi dari aspek komunikasi pembangunan dengan melakukan penilaian terhadap dialog dan tindakan kolektif kelompok tani. Penilaian mengacu pada IMFSC. Penelitian dilakukan di Kecamatan Luyo Provinsi Sulawesi Barat dengan menggunakan metode survei dan bersifat deskriptif korelasional. Jumlah sampel sebanyak 41 kelompok dengan 205 responden. Analisis deskriptif menunjukkan rata-rata bobot rata-rata skor kelompok dalam pelaksanaan community dialogue dan collective action sebesar 56.05, 50.88 dan 65.72 dari skor penilaian maksimal 100. Hasil uji korelasi rank Spearman menunjukkan persepsi petani terhadap tingkat kemudahan diamati pada hasil penerapan standar Sertifikasi Kakao dan peran fasilitator berhubungan secara nyata dengan dialog dan tindakan kolektif kelompok. Dialog dalam kelompok juga memiliki hubungan sangat nyata dengan
\end{abstract}


tindakan kolektif kelompok. Jadi, sebagian kelompok tani memiliki potensi akan terus mengadopsi Standar Sertifikasi Kakao tetapi sebagian lain berpotensi berhenti.

Kata kunci : adopsi inovasi, Sertifikasi Kakao, aksi kolektif, dialog komunitas, fasilitator

\section{PENDAHULUAN}

Program Sertifikasi Kakao dilaksanakan untuk meningkatkan penerapan praktik pengelolaan kakao yang memenuhi standar pertanian berkelanjutan. Program ini bagian dari implementasi komitmen pelaku sektor kakao dunia bagi pemberdayaan petani dalam upaya mewujudkan sustainable cocoa. Karena itu, negara tujuan, industri pengolah hingga NGO mensyaratkan sumber bahan baku kakao yang mereka terima sepenuhnya diproduksi dari praktek budidaya yang menerapkan standar "berkelanjutan". Pemberlakukannya mulai Tahun 2010 dan wajib sepenuhnya di Tahun 2025 (ICCO, 2012). Standar kakao berkelanjutan yang diterima dan diterapkan secara internasional yakni Sertifikasi Kakao.

Isu ini penting bagi Indonesia yang merupakan negara penghasil kakao terbesar ketiga di dunia. Indonesia berkontribusi $17,36 \%$ terhadap total produksi kakao dengan memiliki $16,85 \%$ dari total seluruh luas lahan kakao dunia. Terdapat enam provinsi yang menjadi sentra utama produksi kakao di Indonesia, dan Provinsi Sulawesi Barat merupakan sentra produksi kakao keempat terbesar (Pusdatin Kementan, 2014) dan menyumbang $11-12 \%$ produksi nasional per tahun (Ditjenbun 2016). Jumlah kelompok tani tersertifikasi di Sulawesi Barat hingga Tahun 2017 baru berkisar 8,4\% dari total petani kakao yang ada, berdasarkan data pemegang sertifikat.

Pemerintah mengakui tingkat adopsi petani masih rendah terhadap teknologi baru dalam praktik budidaya perkebunan berkelanjutan. Pemberdayaan yang dilaksanakan juga belum mampu meningkatkan adopsi petani terhadap inovasi tersebut (Ditjenbun, 2016). Perlu dilakukan identifikasi program yang berhasil mendorong adopsi Sertifikasi Kakao secara berkelanjutan. Jika memiliki potensi keberlanjutan yang tinggi maka program ini dapat diarahkan menjangkau petani lebih luas sebelum tenggat waktu yang ditetapkan.

Penelitian terdahulu menunjukkan adopsi praktik Sertifikasi Kakao dipengaruhi faktor keaktifan keanggotaan dalam organisasi petani dan kesadaran pentingnya praktik tersebut (Aidoo dan Fromm, 2015). Kurangnya insentif yang diterima membuat petani kakao enggan menginvestasikan sumberdaya mereka dalam melaksanakan praktik yang direkomendasikan (Quarmine et al., 2012). Penelitian pada komoditi pertanian lainnya juga menunjukkan jika organisasi petani dapat bermanfaat menjadi jalur mendapatkan insentif input usahatani berupa pembiayaan dan benih (Hellin et al. 2009:21) serta wadah bagi tindakan kolektif yang memungkinkan terjadinya adopsi inovasi yang dibutuhkan petani (Koutsou dan Vounouki, 2012).

Berdasarkan beberapa hasil penelitian di atas, mendorong keaktifan kelompok tani dan menumbuhkan tindakan kolektif dalam penerapan standar sertifikasi dapat menjadi faktor kunci terjadinya adopsi Sertifikasi Kakao. Kedua faktor tersebut mempengaruhi dua faktor lainnya yakni kesadaran petani dan tersedianya insentif. Menurut Ife dan Tesoriero (2008) tindakan kolektif dibutuhkan dalam menghadapi permasalahan yang tidak bisa dipecahkan individu. Dapat menjadi tindakan yang jauh lebih kuat dan efektif daripada tindakan individual dan berkontribusi terhadap proses peningkatan kesadaran. 
Kunci keterlibatan dalam implementasi kegiatan kolektif adalah partisipasi (Iqbal, 2007) dan dialog menjadi komunikasi yang tepat dalam membangun partisipasi (Servaes dan Malikhao, 2005).

Memahami keterkaitan antara dialog dengan tindakan kolektif dapat merujuk pada uraian ringkas Figueroa et al. (2002), bahwa pelaksanaan dialog dapat membuat sharing informasi terjadi di antara anggota komunitas sehingga mencapai kesamaan pemahaman dan konsensus, ketika berbagai hal tersebut dicapai akan mendasari anggota komunitas melakukan tindakan kolektif. Hasil penelitian Muslikhah (2015) menunjukkan hal yang sama, dimana tindakan kolektif diantara anggota kelompok wanita tani terjadi sebagai salah satu bentuk refleksi aksi dari hasil voice dan dialog dalam kelompok tersebut. Jadi komunikasi yang berlangsung dialogis ditujukan untuk mengarahkan kepada saling pengertian, persetujuan bersama dan kerjasama (Aminah et al., 2014).

Penelitian ini diarahkan untuk mengkaji keterkaitan komunikasi dialog dengan tindakan kolektif kelompok petani dalam mengadopsi Sertifikasi Kakao. Penelitian dilakukan dengan mengacu pada model komunikasi Community Dialogue dan Collective Action. Model komunikasi ini fokus pada proses dialog sebagai bentuk partisipatif dari komunikasi yang berhubungan dengan tindakan kolektif (Figueroa et al. 2002). Pengukuran peubah penelitian dialog dan tindakan kolektif dengan model komunikasi Community Dialogue dan Collective Actiondapat merujuk pada The Integrated Model for Measuring the Process and its Outcome (IMCFSC) dari Figueroa et al. (2002). Menurut Servaes et al. (2012) IMCFSC adalah satu dari enam kerangka yang dapat digunakan dalam melakukan penilaian dan evaluasi yang sejalan dengan strategi komunikasi pembangunan dengan pendekatan partisipatif.

IMCFSC menggambarkan proses Community Dialogue dan Collective Action dalam suatu kelompok masyarakat baik berlangsung secara sekuensial ataupun simultan (Kincaid dan Figueroa, 2009). Community Dialogue tidak hanya terjadi secara spontan tetapi dapat pula karena adanya katalis. Katalis mendorong terjadinya dialog dalam masyarakat. Ketika dialog berlangsung efektif menyebabkan tumbuhnya tindakan kolektif dan penyelesaian masalah. Dalam model ini, katalis sebagai pemantik utama terjadinya Community Dialogue dapat berupa internal stimulus, agen perubahan, inovasi, kebijakan, ketersediaan teknologi, dan media massa (Figueroa et al., 2002; Kincaid dan Figueroa, 2009). Katalis yang dikaji dalam pelaksanaan penelitian ini yakni inovasi dan agen perubahan. Berdasarkan uraian di atas berikut rumusan masalah yang diajukan dalam penelitian ini adalah (1) Bagaimana dialog dan tindakan kolektif penerapan standar sertifikasi pada kelompok kakao di Kabupaten Polewali Mandar Provinsi Sulawesi Barat ? (2) Bagaimana hubungan antara inovasi dan peran fasilitator dengan dialog dan tindakan kolektif penerapan standar sertifikasi pada kelompok tani kakao di Kabupaten Polewali Mandar Provinsi Sulawesi Barat ? dan (3) Bagaimana hubungan antara dialog dengan tindakan kolektif penerapan standar sertifikasi pada kelompok tani kakao di Kabupaten Polewali Mandar?

\section{TINJAUAN PUSTAKA}

Pembangunan perkebunan di Indonesia dilaksanakan dengan menekankan pendekatan partisipatif. Pendekatan ini diharapkan mampu mendorong munculnya partisipasi yang lebih besar dari masyarakat pekebun mulai dari perencanaan sampai implementasi (Ditjenbun 2016). Bessette (2004) dalam Kincaid dan 
Figueroa (2009) menjelaskan bahwa dalam pembangunan partisipatif, komunikasi merupakan kegiatan yang direncanakan, menggunakan media lokal serta dialog di antara beragam stakeholders. Dialog tentang masalah bersama atau tujuan bersama membangun dan melaksanakan kegiatan yang berkontribusi pada penyelesaian masalah. Stakeholders biasanya bukan saja individu anggota masyarakat itu sendiri, tetapi bisa kelompok dalam masyarakat, otoritas lokal atau regional, NGO, institusi pemerintah yang menyediakan layanan di level masyarakat dan pengambil keputusan (Kincaid dan Figueroa, 2009).

Menurut Kincaid dan Figueroa (2009) model komunikasi yang sejalan dengan pembangunan berbasis pendekatan partisipatif menekankan pada community dialogue dan collective action. Model ini mencoba mengintegrasikan dua paradigma komunikasi pembangunan, yakni model difusi dan partisipatif yang kadang dianggap saling bertolak belakang satu dengan lainnya. Model ini juga berupaya menerjemahkan filosofi partisipasi ke dalam sebuah proses yang efektif memotivasi komunitas untuk bertindak kolektif dan memungkinkan mereka memonitor perkembangan dan meningkatkan kapasitasnya sendiri (Figueroa et al., 2002)

Penerapan community dialogue menarik pemerintah dan masyarakat ke dalam proses yang terbuka dan transparan, mendengarkan secara aktif, terjadi dialog konsultatif, memberdayakan masyarakat dalam mengedukasi diri sendiri, membangun pemahaman informasi dengan sudut pandang berbeda serta meningkatkan partisipasi termasuk dalam pengambilan keputusan (Coyle, 2015). Community dialogue mampu memberikan dampak perubahan sikap yang signifikan dibanding penggunaan pesan media massa konvensional (Egeonu dan Nwachukwu, 2013).

Tahap community dialogue dan collective action dari Figueroa et al. (2002) menggambarkan proses dimana masyarakat mulai mengidentifikasi masalah hingga memutuskan rencana dan melaksanakan tindakan yang akan dilakukan secara kolektif dalam menangani masalah tersebut. Dalam community dialogue dapat berlangsung proses seperti apa yang dimaksudkan sebagai agenda setting dan matching dalam tahapan keputusan adopsi inovasi kolektif yang diuraikan oleh Rogers (2003).

Agenda setting merupakan proses dimana organisasi mengidentifikasi masalah yang mereka hadapi dan kemudian memiliki persepsi bahwa mereka membutuhkan suatu inovasi untuk mengatasi masalah tersebut. Sedangkan tahapan matching berlangsung ketika organisasi mulai menyelaraskan antara masalah yang mereka hadapi dengan pilihan inovasi yang akan mereka adopsi. Ketika kedua tahap tersebut selesai, kemudian lanjut pada proses implementasi yang terdiri dari tahap redifining/restructuring, clarifying dan routinizing. Ketiga tahap menyangkut semua peristiwa, tindakan, dan keputusan yang berkaitan bagaimana menempatkan inovasi agar mulai digunakan. Tingkat partisipasi anggota dalam proses keputusan tersebut menentukan keberlanjutan adopsi inovasi kolektif (Rogers, 2003).

\section{Kerangka Pemikiran}

Tahap community dialogue dan collective action berlangsung ketika kelompok tani mulai mengidentifikasi berbagai masalah yang dihadapi usahatani kakao mereka, dan mulai memilih menerapkan standar Sertifikasi Kakao sebagai salah solusi yang dipilih. Dalam menilai potensi keberlanjutan adopsi Sertifikasi 
Kakao dari aspek komunikasi pembangunan, maka penelitian ini mengukur tingkat partisipasi dan partisipasi komunikasi setiap anggota kelompok dalam kedua tahap tersebut.

Dalam penelitian ini community dialogue dimaknai sebagai dialog dalam kelompok yakni aktivitas komunikasi dua arah diantara anggota kelompok tani, fasilitator dan stakeholders lainnya, dimana masing-masing pihak mau mendengarkan sudut pandang yang lain dan menyampaikan pendapatnya sehingga tercapai konsensus diantara mereka terhadap penerapan Sertifikasi Kakao. Collective action didefinisikan sebagai aktivitas kolektif anggota kelompok dalam melaksanakan rencana kegiatan, mendapatkan manfaat dan melakukan evaluasi capaian dalam rangka memenuhi standar Sertifikasi Kakao.

Penelitian terhadap proses Community Dialogue dan Collective Action kelompok tani dalam Program Sertifikasi Kakao menguji dua dari enam variabel yang bisa menjadi katalis yakni inovasi dan agen perubahan. Karakteristik inovasi Sertifikasi Kakao merujuk pada atribut/ciri sistem pengelolaan kakao yang dianggap baru oleh petani, dan menghasilkan nilai baru pada hasil usahatani kakao sebagai kakao tersertifikasi. Sedangkan peran fasilitator yang dimaksud berkaitan dengan tugas-tugas yang dilakukan oleh seseorang dengan kemampuan dan keterampilan tertentu memfasilitasi petani dalam menerapkan standar sertifikasi kakao. Berikut kerangka pemikiran yang diajukan dalam penelitian ini.

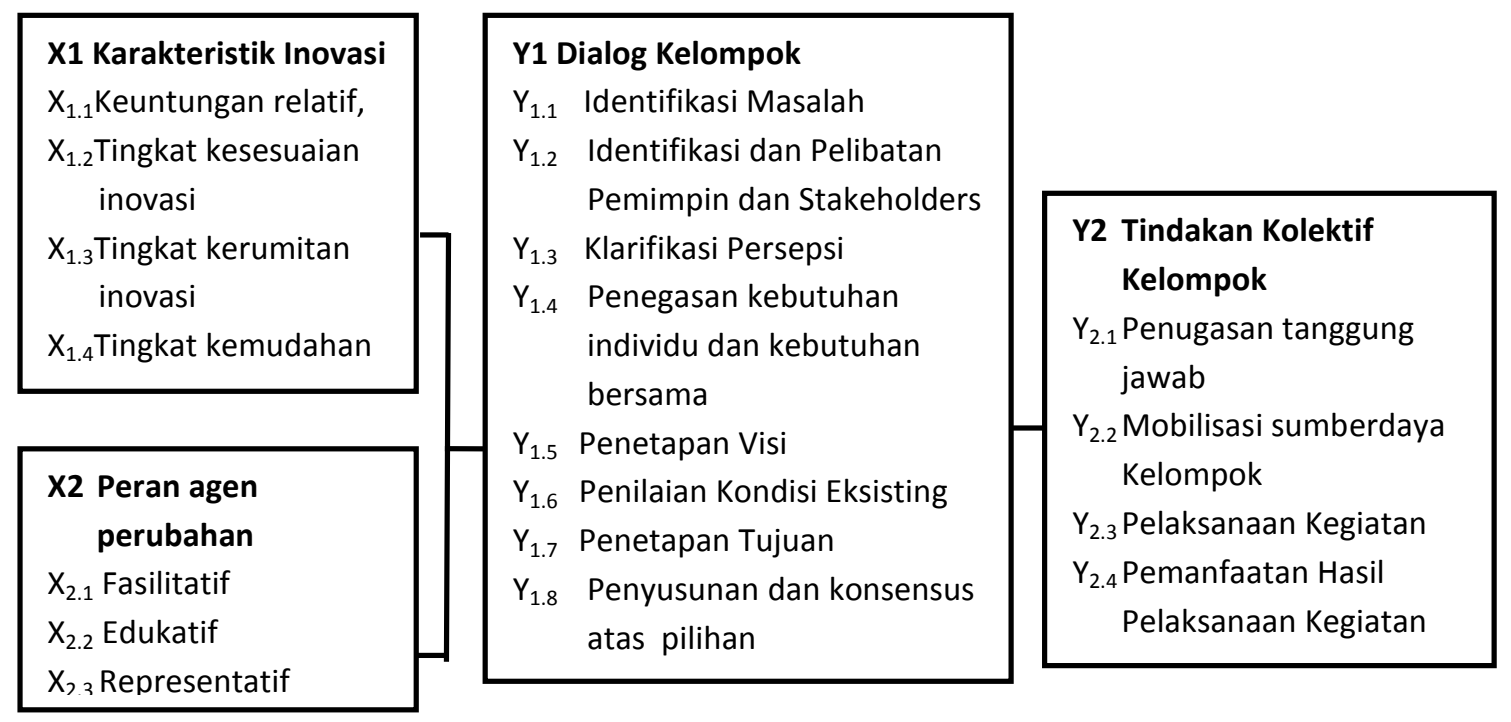

Gambar 1. Kerangka pemikiran dialog kelompok dan tindakan kolektif pada kelompok tani kakao bersertifikasi

Berdasarkan kerangka pemikiran di atas, maka hipotesis yang diajukan dalam penelitian ini sebagai berikut:

1. Terdapat hubungan yang nyata antara karakteristik inovasi dengan dialog dan tindakan kolektif kelompok tani dalam menerapkan standar Sertifikasi Kakao.

2. Terdapat hubungan yang nyata antara peran fasilitator dengan dialog dan tindakan kolektif kelompok tani dalam menerapkan standar Sertifikasi Kakao.

3. Terdapat hubungan yang nyata antara terlaksananya dialog dengan tindakan kolektif kelompok tani dalam menerapkan standar Sertifikasi Kakao. 


\section{METODE PENELITIAN}

Penelitian didesain dengan metode survei dan berbentuk deskriptif korelasional. Penelitian bertujuan menerangkan katalis (inovasi dan fasilitator), dialog dan tindakan kolektif kelompok tanidalam pelaksanaan Program Sertifikasi Kakao serta menganalisis hubungan diantara peubah penelitian tersebut. Penelitian dilaksanakan di Kecamatan Luyo Kabupaten Polewali Mandar Provinsi Sulawesi Barat. Pemilihan lokasi penelitian dilakukan secara purposive karena kecamatan ini sentra kakao dengan jumlah kelompok tani tersertifikasi salah satu yang terbanyak di Kabupaten Polewali Mandar.

Jumlah sampel sebanyak 41 kelompok peserta Program Sertifikasi Kakao, dengan total responden sebanyak 205 anggota/pengurus kelompok. Penarikan jumlah sampel menggunakan formula Slovin terhadap populasi sebesar 69 kelompok tani dengan persen kelonggaran ketelitian sebesar 10\%. Penarikan sampel dilakukan secara acak sederhana sedangkan penentuan responden dilakukan dengan teknik aksidental, tetapi tetap memenuhi jumlah responden tiap kelompok sebanyak 5 orang. Uji validitas dan reliabilitas dilakukan terhadap 30 responden non sampel dari kelompok tani yang juga tersertifikasi pada kecamatan yang berdekatan dengan lokasi penelitian.

Pengumpulan data dilakukan dengan menggunakan kuesioner untuk mengukur penilaian responden terhadap karakteristik inovasi dan peran fasilitator, pelaksanaan dialog serta tindakan kolektif. Untuk memperoleh keakuratan fakta di lapangan dengan interpretasi yang tepat juga dilakukan observasi terhadap pelaksanaan pendampingan teknis oleh fasilitator, pertemuan kelompok dan bentuk tindakan kolektif kelompok, ditambah wawancara langsung anggota/pengurus kelompok dan fasilitator terkait dengan data lapangan yang perlu dilakukan konfirmasi dan diperjelas. Pengukuran dialog untuk setiap topik pada tahap community dialogue dan collective actionmerujuk pada IMFSC, yang meliputi bentuk pelaksanaan dialog, tingkat partisipasi, tingkat dan bentuk penyelesaian perdebatan/konflik hingga bentuk pengambilan keputusan.

Dalam penelitian ini digunakan analisis statistik deskriptif dan analisis statistik inferensial yakni analisis korelasi rank Spearman. Analisis korelasi rank Spearman digunakan untuk melihat hubungan antara katalis dengan dialog dan tindakan kolektif kelompok, serta dialog dan tindakan kolektif itu sendiri. Penentuan skor penilaian kelompok didapatkan dengan menarik nilai rata-rata dari skor penilaian lima responden tiap kelompok. Penyajian tabel statistik destriptif hanya memuat nilai rata-rata kelompok dan standar deviasi ditambah nilai bobot rata-rata skor kelompok. Nilai bobot ini merupakan besaran persentase rata-rata terhadap skor penilaian tertinggi, yang digunakan untuk memudahkan penilaian terhadap katalis dan pelaksanaan community dialogue dan colective action dari lima aspek yang diukur. Nilai bobot ra-rata skor kelompok tertinggi adalah 100 yang menggambarkan kondisi paling ideal dalam pelaksanaan dialog pada lima aspek yang diukur berdasarkan penilaian kelompok tani. 


\section{HASIL DAN PEMBAHASAN}

\section{Katalis}

Pelaksanaan Program Sertifikasi Kakao dilaksanakan pertama kali di Kabupaten Polewali Mandar Tahun 2009 - 2011 oleh PT. Armajaro Indonesia bekerja sama dengan koperasi petani kakao dan pedagang lokal. Program ini terhenti di Tahun 2011 dan dilaksanakan kembali di Tahun 2012 oleh PT. Papandayan Cocoa Industries yang didukung PT. Barry Callebout dan PT Mars Symbioscience Indonesia dengan mitra lokal yang sama. Dalam mendorong adopsi standar Sertifikasi Kakao, dilaksanakan sosialisasi, pelatihan dan pendampingan oleh fasilitator program. Fasilitator selanjutnya berperan menjadi katalis bagi berlangsungnya dialog dalam proses keputusan adopsi standar sertifikasi oleh kelompok tani.

Dalam model IMFSC digambarkan jika dialog dalam suatu komunitas dapat terjadi karena adanya katalis. Penelitian ini menguji katalis berupa inovasi Sertifikasi Kakao dan fasilitator program yang menjalankan peran sebagai agen perubahan. Pengukuran inovasi meliputi penilaian petani terhadap empat dari lima karakteristik inovasi yang sesuai diukur terhadap inovasi Sertifikasi Kakao.

Tabel 1 Rata-rata, standar deviasi dan bobot rata-rata skor penilaian kelompok tani terhadap karakteristik inovasi dalam pelaksanaan Program Sertifikasi Kakao

\begin{tabular}{lccc}
\hline \multicolumn{1}{c}{ Karakteristik Inovasi } & Rata-rata & Standar deviasi & $\begin{array}{c}\text { Bobot rata-rata skor } \\
\text { penilaian kelompok }\end{array}$ \\
\hline Keuntungan relatif & 7.63 & 0,64 & 76.29 \\
Tingkat kesesuaian inovasi & 9.40 & 1,25 & 78.33 \\
Tingkat kerumitan inovasi & 5.35 & 0,67 & 59.46 \\
Tingkat kemudahan & 7.02 & 0,77 & 78.05 \\
diamati & & & \\
\hline
\end{tabular}

Hasil penelitian pada Tabel 1 menunjukkan penilaian petani terhadap karakteristik inovasi rata-rata di atas nilai 75 , kecuali bobot rata-rata skor kelompok untuk penilaian tingkat kerumitan. Dari nilai standar deviasi yang jauh lebih kecil dari rata-rata dapat diketahui jika sebaran datanya tidak jauh dari ratarata. Bobot rata-rata skor kelompok sebesar 76.29 menggambarkan sebagian besar kelompok tani menilai telah mendapatkan keuntungan berupa peningkatan harga jual kakao, peningkatan produksi dan penurunan biaya usahatani dibandingkan sebelum menerapkan standar Sertifikasi Kakao. Sebaliknya, beberapa kelompok yang memiliki skor penilaian rendah menunjukkan bahwa anggota kelompok mendapatkan keuntungan baru sebatas adanya premium fee dan harga jual yang meningkat. Biaya usahatani malah meningkat dan produksi masih sama bahkan mengalami penurunan di Tahun 2017.

Kelompok tani umumnya menilai bahwa anjuran teknis dalam Sertifikasi Kakao yang agak berbeda dengan kebiasaan berkebun cukup bisa diterima dan diikuti. Penilaian kelompok tani untuk tingkat kesesuaian inovasi tergolong cukup tinggi, sebesar 78.33. ini menunjukkan sebagian mulai menggunakan pupuk yang diolah dari limbah ternak, tidak lagi membakar sampah hasil pemangkasan dan pembersihan gulma dalam areal kebun serta tidak melibatkan anak di bawah umur 15 tahun melebihi jam kerja yang diperbolehkan. Pelibatan anak-anak kinipun pun terbatas pada saat panen dan pasca panen. 
Berkaitan dengan adanya pemahaman dari pelatihan GAP sebelumnya, rata-rata kelompok tani tidak lagi menganggap standar Sertifikasi Kakao lebih rumit dari praktik budidaya yang sebelumnya dilakukan. Walaupun begitu hampir tidak ada kelompok yang menganggap lebih mudah, berdasarkan bobot rata-rata skor kelompok sebesar 59.46. Kelompok tani yang menilai lebih rumit memberi penekanan jika hal tersebut mereka rasakan pada standar pengendalian hama dan penyakit dengan mengurangi atau meniadakan penggunaan pestisida yang dinyatakan terlarang dan penerapan pencatatan penjualan kakao.

Sebagian besar kelompok tani menilai penerapan standar sertifikasi secara menyeluruh membuat hasilnya mudah diamati. Ditunjukkan oleh bobot rata-rata skor kelompok untuk penilaian kemudahan diamati sebesar 78.05. Mereka mengakui cukup mudah mengamati jumlah tanaman yang terbebas dari hama dan penyakit serta jumlah buah yang masih baik dan siap panen, tetapi masih sulit pada kondisi kesuburan tanah/lahan kebun. Perubahan kondisi tanah diakui baru tampak pada lahan yang sudah lama menerapkan standar sertifikasi dan tidak lagi menggunakan pestisida.

Tabel 2 Rata-rata, standar deviasi dan bobot rata-rata skor penilaian kelompok tani terhadap peran fasilitator dalam pelaksanaan Program Sertifikasi Kakao

\begin{tabular}{lccc}
\hline \multicolumn{1}{c}{ Peran Fasilitator } & Rata-rata & Standar deviasi & $\begin{array}{c}\text { Bobot rata-rata skor } \\
\text { penilaian kelompok }\end{array}$ \\
\hline Peran Fasilitatif & 7.24 & 1.42 & 65.81 \\
Peran Edukatif & 6.05 & 0.94 & 75.61 \\
Peran Representatif & 5.01 & 0.57 & 83.42 \\
\hline
\end{tabular}

Penilaian kelompok tani terhadap peran fasilitator dalam pelaksanaan program memiliki bobot rata-rata skor kelompok meliputi peran fasilitatif, edukatif dan representatif berturut-turut sebesar 65.81, 75.61 dan 83.42 (Tabel 2). Ini menunjukkan jika fasilitator memfasilitasi pertemuan dan menggerakkan kerja kelompok sebagian besar dilaksanakan satu kali dalam sebulan. Ada beberapa kelompok tani yang cukup aktif dengan akses lokasi yang baik mendapatkan hingga 2 kali kunjungan per bulan. Anggota kelompok tani yang menyampaikan pendapat dalam setiap pertemuan ataupun dialog kurang dari $50 \%$.

Peran edukatif yang dijalankan fasilitator sebagian dilaksanakan dua kali dalam sebulan. Peran edukatif meliputi pelaksanaan sosialisasi, pelatihan dan pendampingan teknis. Sosialisasi program tidak hanya dilaksanakan diawal pelaksanaan tetapi dilakukan secara periodik. Bertambahnya kriteria teknis yang harus dipenuhi setiap tahunnya oleh kelompok tani dan adanya audit secara reguler dan insidental membuat fasilitator harus melakukan sosialisasi pada waktu-waktu tertentu. Fasilitator tidak mensosialisasikan sekaligus seluruh ketentuan program tetapi secara bertahap sesuai dengan standar kriteria tahun audit serta mempertimbangkan kapasitas petani dalam memahami dan melaksanakan setiap standar Sertifikasi Kakao. Untuk pendampingan teknis lebih banyak diberikan dalam kelompok kecil ataupun kunjungan ke kebun anggota kelompok.

Bobot rata-rata skor penilaian kelompok tani terhadap pelaksanaan peran representatif tergolong tinggi. Sebagian besar kelompok tani menilai fasilitator setidaknya membantu mereka berhubungan dengan mitra satu kali dalam setahun. Kelompok tani tetap menilai dibantu atau diwakili sekalipun fasilitasi pengajuan 
bantuan belum disetujui atau hanya terealisasi dalam bentuk pinjaman berupa pupuk. Diniai positif karena pinjaman ini bersifat lunak yakni bisa dilunasi setelah hasil panen kakao selesai dipasarkan. Fasilitator juga dinilai berperan bagi kelompok tani dalam mendapatkan bantuan pelatihan walaupun tidak selalu menjangkau seluruh anggota kelompok.

\section{Dialog dan Tindakan Kolektif Kelompok}

Hasil pengukuran tingkat pelaksanaan community dialogue dan collective action kelompok tani tersertifikasi disajikan dalam Tabel 3 dan Tabel 4. Ada lima belas topik dialog yang dicantumkan dalam IMFSC tetapi tidak semua kelompok membahas kelima belas topik tersebut dalam proses mereka mengadopsi standar Sertifikasi Kakao. Untuk dialog penyusunan opsi kegiatan dibahas sekaligus dengan kesepakatan terhadap opsi kegiatan yang dipilih. Lima topik dibahas pada seluruh kelompok, enam topik dibahas lebih dari $75 \%$ kelompok dan sisanya tiga topik dialog dibahas kurang dari $60 \%$ kelompok. Kecuali pada penilaian kondisi eksisting (56.85), topik yang paling banyak didialogkan juga menunjukkan bobot rata-rata skor penilaian kelompok lebih tinggi, meliputi klarifikasi persepsi (72.49) penilaian kondisi eksisting (63.32) penyusunan rencana kegiatan (69.22) dan pelaksanaan rencana (75.50).

Tabel 3 Persentase jumlah kelompok, rata-rata, standar deviasi, dan bobot rata-rata skor penilaian kelompok terhadap dialog perencanan dan persiapan penerapan standar Sertifikasi Kakao

\begin{tabular}{|c|c|c|c|}
\hline Topik Dialog (Tahap Community Dialogue) & $\begin{array}{c}\text { Pelaksanaan } \\
(\%)\end{array}$ & $\begin{array}{c}\text { Rata-rata } \\
\text { (standar deviasi) }\end{array}$ & $\begin{array}{l}\text { Bobot rata-rata skor } \\
\text { penilaian kelompok }\end{array}$ \\
\hline Identifikasi masalah & 92.68 & $10.24(4.07)$ & 51.22 \\
\hline Identifikasi dan pelibatan stakeholders & 56.10 & $5.73(5.50)$ & 28.63 \\
\hline Klarifikasi persepsi & 100.00 & $14.50(2.48)$ & 72.49 \\
\hline $\begin{array}{l}\text { Penyampaian kebutuhan individu dan } \\
\text { kebutuhan bersama }\end{array}$ & 95.12 & $12.37(3.79)$ & 61.83 \\
\hline Penetapan visi & 97.6 & $10.80(2.95)$ & 54.00 \\
\hline Penilaian kondisi eksisting & 100.0 & $12.66(1.92)$ & 63.32 \\
\hline Penetapan tujuan & 78.05 & $8.43(5.02)$ & 42.15 \\
\hline Penyusunan opsi kegiatan dan & 92.68 & $12.30(4.50)$ & 61.49 \\
\hline Membangun konsensus atas pilihan kegiatan & & & \\
\hline Penyusunan rencana kegiatan & 100.00 & $13.84(2.15)$ & 69.22 \\
\hline \multicolumn{3}{|c|}{ Rata-rata (bobot rata-rata skor penilaian kelompok terhadap dialog kelompok) } & 56.05 \\
\hline \multicolumn{4}{|l|}{ Topik Dialog Dalam Tahap Collective Action } \\
\hline Penugasan tanggung jawab & 58.54 & $6.31(5.68)$ & 31.55 \\
\hline Mobilisasi sumberdaya & 46.36 & $8.63(6.04)$ & 43.15 \\
\hline Pelaksanaan rencana kegiatan & 100.00 & $15.10(2.10)$ & 75.50 \\
\hline Pemanfaatan hasil & 85.37 & $9.47(4.57)$ & 47.35 \\
\hline Evaluasi partisipatif & 100.00 & $11.37(1.50)$ & 56.85 \\
\hline \multicolumn{3}{|c|}{$\begin{array}{l}\text { Rata-rata (bobot rata-rata skor penilaian dialog mengatur tindakan kolektif } \\
\text { kelompok) }\end{array}$} & 50.88 \\
\hline
\end{tabular}

Semua kelompok membahas kelima topik tersebut karena dianggap memiliki pengaruh besar dan menghasilkan keputusan penting dalam proses keikutsertaan kelompok sebagai peserta program. Nilai standar deviasi yang ditunjukkan dalam Tabel 3 juga jauh lebih kecil dari nilai rata-rata skor kelompok. ini menunjukkan jika tingkat partisipasi/partisipasi komunikasi dalam dialog topik ini sebagian besar sama di semua kelompok. Dialog yang dilaksanakan memberikan akses berpartisipasi yang sama bagi semua anggota kelompok termasuk dalam pengambilan keputusan. Jika ada anggota tidak hadir tetap 
dilakukan konfirmasi atas apa yang diputuskan. Tujuannya agar mendapatkan komitmen anggota terhadap keputusan kelompok. Penilaian kondisi eksisting yang bobot skor rata-rata penilaian kelompok lebih rendah, karena pada topik ini dialog lebih banyak dilakukan dalam bentuk kunjungan langsung ke rumah dan kebun anggota dibanding pertemuan kelompok. Dalam melakukan penilaian kondisi eksisting kebun, masih terdapat kelompok yang lebih fokus pada anggota yang terpilih sebagai sampel audit dan menunda penilaian pada anggota non sampel. Sehingga partisipasi tidak terjadi pada semua anggota kelompok.

Kondisi sebaliknya terjadi pada topik dialog dengan persentase jumlah kelompok yang melaksanakan rendah dan nilai bobot rata-rata pelaksanaan yang juga rendah. Hal ini dipengaruhi anggapan beberapa topik itu kurang penting dan tidak akan berpengaruh besar pada kesiapan kelompok menghadapi audit sertifikasi. Sehingga dominan hanya dibicarakan di tingkat pengurus dan fasilitator, bahkan terdapat kelompok yang tidak membahasnya sama sekali. Artinya akses dan tingkat partisipasi bagi anggota kelompok lainnya rendah, termasuk dalam pengambilan keputusan.

Secara keseluruhan bobot rata-rata skor penilaian kelompok terhadap pelaksanaan dialog tahap community dialogue sebesar 56.05 dan tahap collective action sebesar 50.88. Jika melihat seluruh nilai standar deviasi setiap topik dialog di Tabel 3, maka ini mengindikasikan jika akses dan tingkat partisipasi komunikasi dalam mengikuti dialog, mengajukan pendapat, menyelesaikan perdebatan dan mengambil keputusan sebagian rendah dan sebagian kelompok lainnya sudah cukup tinggi. Sebaran skor penilaian dialog seluruh kelompok cukup bervariasi yakni terendah 31.44 dan tertinggi 78.33. Kecenderungan yang terjadi adalah makin lama kelompok tani menjadi peserta program makin tinggi skor penilaian pelaksanaan dialognya. Kelompok tani yang baru menjadi peserta program dalam kurun waktu $1-2$ tahun sebagian besar memiliki skor rendah, antara lain karena tidak membahas beberapa topik serta dominan hanya melibatkan pengurus dan beberapa anggota dalam dialog termasuk dalam pengambilan keputusan.

Tabel 4 Persentase jumlah, nilai rata-rata, standar deviasi dan bobot rata-rata skor penilaian kelompok terhadap pelaksanaan tindakan kolektif dalam penerapan standar Sertifikasi Kakao

\begin{tabular}{lccc}
\hline $\begin{array}{c}\text { Tindakan Kolektif } \\
\text { (Tahap Collective Action) }\end{array}$ & $\begin{array}{c}\text { Pelaksanaan } \\
\text { (\% jumlah klp) }\end{array}$ & $\begin{array}{c}\text { Rata-rata } \\
\text { (standar deviasi) }\end{array}$ & $\begin{array}{c}\text { Bobot rata-rata skor } \\
\text { penilaian kelompok }\end{array}$ \\
\hline Penugasan tanggung jawab & 75,61 & $2.32(0.65)$ & 75.61 \\
Mobilisasi sumberdaya & 100.00 & $5.44(0.95)$ & 60.44 \\
Pelaksanaan rencana aksi & 100.00 & $20.55(1.90)$ & 64.21 \\
Pemanfaatan hasil & 100.00 & $2.43(0.47)$ & 60.85 \\
Evaluasi partisipatif & 100.00 & $2.63(0.66)$ & 65.85 \\
\hline \multicolumn{2}{c}{ Rata-rata (bobot rata-rata skor penilaian tindakan kolektif kelompok) } & 65.72 \\
\hline
\end{tabular}

Secara keseluruhan tingkat partisipasi pelaksanaan tindakan kolektif penerapan standar sertifikasi lebih tinggi dibandingkan dialog perencanaan tindakan kolektif, kecuali pada dialog penyusunan rencana kegiatan. Bobot ratarata skor penilaian kelompok terhadap pelaksanaan dialog mengatur tindakan kolektif lebih tinggi dibandingkan melaksanakan tindakan kolektif. Ada dua hal yang umum terjadi yakni, sebagian besar anggota terlibat dalam dialog tetapi ketika tidak terpilih sebagai sampel audit mereka menunda beberapa penerapan standar sertifikasi, atau dominan anggotanya tidak mengerjakannya dengan kerja 
kelompok tetapi menyelesaikan di kebun masing-masing. Kerja kelompok maupun kerja individu anggota tetap membentuk tindakan kolektif di level kelompok karena secara kolektif semua anggota kelompok peserta program memenuhi standar sertifikasi yang dipersyaratkan dalam code of conduct Sertifikasi Kakao dari lembaga sertifikasi.

Pelaksanaan rencana aksi yang dominan dilaksanakan dengan kerja kelompok antara lain pemangkasan, pembabatan rumput, pemupukan, dan penyediaan perlengkapan kebun. Ada dua istilah lokal yang umum digunakan, yakni "sikalu-kalu" dan "sibali-wali" yang bisa diterjemahkan sebagai saling membantu atau saling membantu yang wajib berbalasan. Untuk tindakan kolektif pelaksanaan monitoring dan evaluasi partisipatif dalam program ini dilakukan oleh Internal Managemen System (IMS) atau Internal Control System (ICS) yang dibentuk oleh pemegang sertifikasi/mitra kelompok tani. Sebagian petugas IMS direkrut dari orang lokal atau anggota kelompok tani. Tugas mereka memastikan bahwa kelompok tani aktif dan tetap memenuhi standar sehingga setiap waktu siap ketika dilakukan audit. Bentuk pelaksanaan dilakukan dengan kunjungan langsung ke kebun-kebun anggota kelompok.

Pada Tabel 4, tahap pelaksanaan tindakan kolektif memiliki bobot rata-rata skor kelempok untuk seluruh penilaian ang lebih baik dari proses dialognya. Bobot rata-rata skor penilaian kelompok sebesar $65,72 \%$ untuk penilaian keseluruhan tindakan kolektif. Ini menunjukkan kalau anggota memiliki akses dan tingkat partisipasi dalam pelaksanaan tindakan kolektif lebih tinggi dibanding akses dan tingkat partisipasi komunikasi ketika tindakan kolektif direncanakan. Tindakan kolektif memiliki akar pada kebiasaan yang sudah ada sebelumnya, seperti gotong royong atau kerja kelompok dalam bentuk arisan tenaga kerja. Sedangkan partisipasi komunikasi menjadi hal baru bagi sejumlah anggota kelompok seperti tergambar dari penyampaian beberapa ketua kelompok, bahwa umumnya anggota kelompok ingin menyampaikan pendapat tapi sulit mengemukakannya untuk didengarkan oleh pengurus, anggota kelompok lainnya dan fasilitator.

Pemanfaatan hasil sebagai kelompok peserta program berupa produksi kakao mereka diperdagangkan sebagai kakao tersertifikasi melalui mitra pemasaran yang sekaligus sebagai pemegang sertifikat. Setiap kakao tersertifikasi mendapat premium fee sebesar Rp. 700/kg, akan tetapi bobot skor rata-rata skor penilaian kelompok sebesar 60.85 menunjukkan jika masih banyak kelompok yang anggotanya mendapatkan premium fee di bawah dari nilai tersebut. Ini terjadi pada anggota kelompok yang menjual kakao tidak langsung kepada mitra pemasaran tetapi melalui jalur tengkulak dengan kondisi kakao belum memenuhi persentase kadar air yang dipersyaratkan. Para tengkulak yang kemudian melanjutkan proses penjemuran, sehingga premium fee dibagi antara tengkulak dan anggota kelompok.

\section{Hubungan antara katalis dengan dialog dan tindakan kolektif kelompok}

Hasil uji korelasi rank Spearman menujukkan hampir semua karakteristik inovasi tidak memiliki hubungan yang nyata dengan tahap community dialogue dan collective action dalam kelompok (Tabel 6). Artinya, hipotesis terdapat 
hubungan secara nyata antara karakteristik inovasi dengan community dialogue dan collective action ditolak.

Tabel 5 Koefisen korelasi rank Spearman antara karakteristik inovasi dan peran fasilitator dengan dialog dan tindakan kolektif kelompok tani dalam penerapan standar Sertifikasi Kakao

\begin{tabular}{ccc}
\hline Katalis & $\begin{array}{c}\text { Dialog } \\
\text { (Tahap Community Dialogue) }\end{array}$ & $\begin{array}{c}\text { Tindakan Kolektif } \\
\text { (Tahap Collective Action) }\end{array}$ \\
\hline Karakteristik Inovasi &, $358^{*}$ &, $309^{*}$ \\
$\quad$ Tingkat kemudahan diamati & &, $465^{* *}$ \\
Peran Fasilitator & $.597^{* *}$ &, $413^{* *}$ \\
Peran Fasilitatif & $.648^{* *}$ &, 236 \\
Peran Edukatif & $.336^{*}$ &, 236 \\
Peran Representatif &
\end{tabular}

Ket.: * Berhubungan nyata pada $\alpha=0,05 . \quad * *$ Berhubungan nyata pada $\alpha=0,01$

Hanya tingkat kemudahan diamati yang memiliki hubungan secara nyata dengan kedua tahap tersebut, koefiesien korelasi masing-masing sebesar 0,358 dan 0,309. Penilaian positif anggota kelompok berdasarkan hasil pengamatan mereka terhadap perubahan kondisi tanaman kakao, buah kakao dan kondisi lahan peserta program yang lebih dulu atau hasil yang mereka capai, berhubungan secara nyata dengan tahap community dialogue dan collective action. Tingkat partisipasi dan partisipasi komunikasi dalam kedua tahap tersebut meningkat ketika mereka mudah mengamati hasil positif penerapan budidaya standar Sertifikasi Kakao. Sedangkan keuntungan relatif, tingkat kesesuaian inovasi dan tingkat kerumitan tidak memiliki hubungan secara nyata dengan kedua tahap tersebut.

Berbeda dengan karakteristik inovasi, hasil uji korelasi terhadap semua peran yang dijalankan fasilitator menunjukkan hubungan nyata dengan tahap community dialogue dan collective action kelompok tani, kecuali pada hubungan peran representatif dengan dengan tindakan kolektif. Ini dapat dikecualikan sebab fasilitator memang tidak diarahkan secara khusus untuk melakukan peran ini. Bahkan dihindari untuk membicarakan akses peluang bantuan dari luar program jika kelompok belum memiliki pemahaman terhadap tugas pendampingan yang utama dilakukan fasilitator terhadap kelompok. Fasilitasi bagi kelompok mendapatkan bantuan input dilakukan secara hati-hati, agar kelompok tidak berkesimpulan jika hal tersebut bersifat bagian wajib dalam pendampingan pelaksanaan program. Dengan demikian hipotesis terdapat hubungan secara nyata antara peran fasilitator dengan community dialogue dan collective action dapat diterima. Meningkatnya frekuensi fasilitator melaksanakan fasilitasi, edukasi dan menjadi penghubung kelompok dengan mitra maka makin tinggi keterlibatan (partisipasi dan partisipasi komunikasi) anggota kelompok dalam community dialogue dan collective action pelaksanaan Program Sertifikasi Kakao.

Hasil penelitian menunjukkan adanya hubungan nyata antara peran fasilitatif dan edukatif dengan berlangsungnya dialog (community dialogue) dan tindakan kolektif (collective action) kelompok dalam menerapkan standar sertifikasi. Ini dapat menjadi indikasi jika fasilitator telah mampu menjalankan peran sebagai catalist dan facilitator seperti yang didefinisikan oleh Toomey (2009). Menurut Toomey (2009) kedua jenis peran yang dijalankan pelaku pemberdayaan ini mampu menumbuhkan keberdayaan masyarakat. Peran ini 
dapat dicapai antara lain karena fasilitator sekaligus menjadi petugas IMS/ICS yang terlibat melakukan evaluasi internal kelompok dalam satu sertifikat kakao secara terus menerus. Sehingga kemajuan kelompok dapat diketahui setiap saat.

Frekuensi kunjungan fasilitator menjalankan berbagai peran fasilitator berhubungan secara nyata dengan pelaksanaan tindakan kolektif kelompok menerapkan standar sertifikasi dalam penelitian ini. Jika dikaitkan dengan temuan Aidoo dan Fromm (2015) yang menunjukkan frekuensi kunjungan penyuluh yang tinggi tidak secara signifikan berdampak positif pada adopsi Sertifikasi Kakao, melainkan faktor kesadaran petani yang signifikan memiliki dampak positif terhadap adopsi, maka hal ini mengarahkan jika korelasi positif antara frekuensi pelaksanaan peran fasilitator mungkin telah mampu menumbuhkan kesadaran petani tentang pentingnya Sertifikasi Kakao. Pelaksanaan di lapangan menunjukkan jika fasilitator memahami pentingnya kesadaran petani. Koordinator fasilitator/IMS menyampaikan bahwa penguasaan teknis budidaya anggota kelompok sudah cukup baik, kebutuhan mereka lebih pada dorongan dan motivasi secara terus menerus agar konsisten menerapkan standar sertifikasi.

\section{Hubungan antara dialog dengan tindakan kolektif kelompok}

Dialog dan tindakan kolektif kelompok tani dalam pelaksanaan Program Sertifikasi Kakao menunjukkan hubungan sangat nyata berdasarkan hasil uji korelasi rank Spearman. Hipotesis terdapat hubungan secara nyata antara dialog tahap community dialogue dengan tindakan kolektif kelompok tani tersertifikasi dalam tahap collective action dapat diterima. Makin terbukanya akses dan tingkat partisipasi anggota kelompok pada setiap dialog yang dilakukan dalam rangka perencanaan dan persiapan pelaksanaan Program Sertifikasi Kakao, maka makin tinggi keterlibatan mereka dalam berbagai kegiatan kolektif dalam menerapkan standar Sertifikasi Kakao di tingkat kelompok. Jika merujuk pada temuan Egeonu dan Nwachukwu (2013), maka perubahan sikap anggota kelompok terhadap standar sertifikasi makin positif seiring meningkatnya partisipasi mereka dalam dialog dalam kelompok yang membahas berbagai hal tersebut.

Tabel 6 Koefisen korelasi rank Spearman antara dialog dengan tindakan kolektif kelompok tani dalam penerapan standar Sertifikasi Kakao

\begin{tabular}{lc}
\hline Dialog & Tindakan Kolektif (Tahap Collective Action) \\
\hline Tahap Community Dialogue &, $510^{* *}$ \\
\hline
\end{tabular}

Ket. $\quad * *$ Berhubungan sangat nyata pada $\alpha=0,01$

Tindakan kolektif pada komunitas petani kakao di Kecamatan Luyo Kabupaten Polewali Mandar berbasis kelompok tani dengan anggota yang homogen, umumnya didasari hubungan kekerabatan satu sama lain dan kebiasaan tindakan kolektif sebelumnya seperti gotong royong, broker berasal dari anggota mereka sendiri. Menurut Koutsou dan Vounouki (2012) tindakan kolektif dengan karakteristik seperti ini memungkinkan berlangsungnya inovasi. Koefisien korelasi yang pada Tabel 6 menunjukkan hubungan nyata antara tahap community dialogue dengan collective action. Meningkatkan pelaksanaan tahap community dialogue akan menumbuhkan atau meneguhkan collective action dalam kelompok tani kakao tersertifikasi. Karena tindakan kolektif dapat salah kunci dalam adopsi Sertifikasi Kakao, maka Program Sertifikasi Kakao dapat menggunakan community dialogue sebagai pendekatan atau program komunikasi. 


\section{KESIMPULAN DAN SARAN}

Hasil penilaian terhadap dialog dan tindakan kolektif pada kelompok tani kakao yang telah tersertifikasi menunjukkan akses dan tingkat partisipasi dan partisipasi komunikasi masih kurang dari aspek mengikuti pertemuan, menyampaikan pendapat, menyelesaikan perbedaan pendapat dan mengambil keputusan. Tingkat partisipasi dan partisipasi komunikasi yang ada belum menjamin keberlanjutan adopsi inovasi Sertifikasi Kakao pada semua kelompok tani kakao. Berdasarkan Rogers (2003) dalam menilai potensi keberlanjutan adopsi inovasi kolektif dari aspek tingkat partisipasi dalam dialog dan tindakan kolektif dari anggota kelompok, dapat dikatakan baru sebagian kelompok berpotensi mengadopsi standar sertifikasi secara berlanjut.

Secara keseluruhan penilaian kelompok tani terhadap karakteristik inovasi tidak memiliki hubungan secara nyata, kecuali pada tingkat kemudahan diamati. Makin mudah hasil penerapan praktik budidaya standar Sertifikasi Kakao mereka amati makin tinggi tingkat partisipasi mereka dalam dialog dan tindakan kolektif kelompok sebagai peserta Program Sertifikasi Kakao. Peran fasilitator memiliki hubungan secara dan sangat nyata dengan dialog dan tindakan kolektif kelompok tani. Temuan ini sejalan dengan apa yang diuraikan Figueroa et al. (2002) agen perubahan dapat menjadi katalis bagi tumbuhnya dialog dan tindakan kolektif. Sedangkan inovasi Sertifikasi Kakao dapat menjadi katalis ketika anggota kelompok tani mudah menemukan dampak positif penerapan standar ini dalam pengelolaan kakao. Peningkatan partisipasi anggota kelompok tani dalam dialog dan tindakan kolektif bisa mempertimbangkan intervensi pada kedua faktor ini.

Terdapat hubungan yang sangat nyata antara dialog dengan tindakan kolektif. Hal ini menggambarkan jika makin tinggi partisipasi anggota kelompok tani dalam dialog merencanakan penerapan standar sertifikasi maka makin tinggi partisipasi dalam melaksanakan tindakan kolektif penerapan standar sertifikasi tersebut. Berdasarkan temuan penelitian ini, dari aspek komunikasi pembangunan, potensi keberlanjutan adopsi standar Sertifikasi Kakao dapat ditingkatkan salah satunya dengan pendekatan community dialogue dalam menumbuhkan kesadaran anggota kelompok tani dan partisipasi mereka dalam tindakan kolektif penerapan standar sertifikasi. Hanya perlu penekanan perbaikan penyelenggaraan dialog, terutama pelibatan seluruh anggota kelompok termasuknya yang paling rentan mengalami kesulitan memenuhi standar sertifikasi. Sehingga masalah dan solusi pemecahan datang dari semua pihak dalam kelompok, sebagaimana penekanan Figueroa et al. (2002) dalam model ini. Pendekatan community dialogue ini dapat menggunakan fasilitator sebagai katalis.

\section{DAFTAR PUSTAKA}

Aidoo R, Fromm I. (2015). Willingness to Adopt Certifications and Sustainable Production Methods among Small-Scale Cocoa Farmers in the Ashanti Region of Ghana. Journal of Sustainable Development, 8(1):33-43. DOI:10.5539/jsd.v8n1p33.

Aminah S. 2014. Perubahan Model Komunikasi Dan Pergeseran Paradigma Pembangunan Dalam Perspektif Sejarah. Paramita: Historical Studies Journal,24(1):92-103.http://journal.unnes.ac.id/nju/index.php/paramita/article/ view/2866.

[CSP] Cocoa Sustainability Partnership. 2013. Cokelat Magazine \#05. 31 Juli 2013. https://issuu.com /cspindonesia/docs/masalah_cokelat_indo_final_low 
[Ditjenbun] Direktorat Jenderal Perkebunan Kementerian Pertanian. 2016. Rencana Strategis Direktorat Jenderal Perkebunan Tahun 2015 - 2019. Edisi Revisi.

Egeonu NE, Nwachukwu I. 2013. Effects Of Unicef Promoted Community Dialogue On

The Attitude Of Farmers Towards Malaria Prevention And Control In Imo State

Nigeria. Journal of Agriculture and Social Research, 13(1):9-14.

Figueroa ME, Kincaid DL, Rani M, Lewis G. 2002. Communication For Social Change:

An Integrated Model For Measuring The Process and Its Outcomes. The Communication for Social Change Working Paper Series: No.1. New York (USA).

Coyle FJ. 2015. 'Best Practice' Community Dialogue: The Promise of a SmallScaledeliberative Engagement Around The Siting of a Carbon Dioxidecapture and Storage (Ccs)Facility. International Journal of Greenhouse Gas Control, 45 (2016) 233-244. DOI:10.1016/j.ijggc.2015.12.006.

Hellin J, Lundy M, Meijer M. 2009. Farmer organization, Collective Action and Market Access in Meso-America. Food Policy, 34(1):16-22. DOI: 10.1016/j.foodpol. 2008.10.003

[ICCO] The International Cocoa Organization. Study on the costs, advantages and disadvantages of cocoa certification. https://www.icco.org/aboutus/international-cocoa-agreements/doc_download/302-study-on-the-costsadvantages-and-disadvantages-of-cocoa-certification-october-2012.html

Ife J, Tesoriero F. 2008. Community Development: Alternatif Pengembangan Masyarakat di Era Globalisasi. Yogyakarta (ID). Pustaka Pelajar.

Iqbal M. 2007. Analisis Peran Pemangku Kepentingan Dan Implementasinya Dalam Pembangunan Pertanian. Jurnal Litbang Pertanian,26(3): 89-99. http://pustaka. litbang.pertanian.go.id/publikasi/p3263071.pdf.

Koutsou S, Vounouki E. 2012. Collective Action And Innovation In Rural Areas: An Efficient Dialogue A Case Study Of Greece. Ager, 13:85-106. DOI: 10.4422/ager.2012.06

Muslikhah FP. 2015. Komunikasi Partisipatif Pada Kelompok Wanita Tani di Kecamatan Kajoran Kabupaten Magelang [tesis]. Bogor (ID). Institut Pertanian Bogor.

[Pusdatin Kementan] Pusat Data dan Sistem Informasi Pertanian Kementerian Pertanian. 2014. Outlook Komoditi Kakao. Jakarta. Pusat Data dan Sistem Informasi Pertanian Sekretariat Jenderal - Kementerian Pertanian.

Quarmine W, Haagsma R, Sakyi-Dawson O, Asante F, van Huis A, Obeng-Ofori D. 2012. Incentives for cocoa bean production in Ghana: Does quality matter? NJASWageningen Journal of Life Sciences, 60:7-14. DOI:10.1016/j.njas.2012.06.009

Rogers EM. 2003. Diffusion of Innovations: $5^{\text {th }}$ edition. New York (USA). Free Press. http://www.ebook777.com/diffusion-innovations-5th-edition/

Servaes J, Malikhao P. 2005. Participatory communication: The New Paradigm. Di dalam Hemer O, Tufte T, editor. Media \&Global Change. Rethinking Communication for Development. Buenos Aires (AR): Publicaciones Cooperativas. hlm 91-103. http://biblioteca.clacso.edu.ar/ar/libros/edicion/media/09Chapter5. pdf

Servaes J, Polk E, Shi SONG, Reilly D, Yakupitijage T. 2012. Towards a Framework of Sustainability Indicators For 'Communication For Development and Social Change' Projects. Internatioal Communication Gazette,74(2):99-123.DOI: 10.1177/1748048511432598.

Toomey AH. 2009. Empowerment and Disempowerment In Community Development Practice: Eight Roles Practitioners Play. Community Development Journal, 46 (2): 181-195. DOI:10.1093/cdj/bsp060. 